\title{
PENGARUH MEDIA MOBILE LEARNING DAN KEMAMPUAN METAKOGNITIF TERHADAP KETERAMPILAN PROSES SAINS SISWA
}

\author{
Lumy Setia Pillena $^{1^{*}, \text { Ucu Cahyana }}{ }^{1}$ dan Agung Purwanto ${ }^{1}$ \\ ${ }^{7}$ Program Studi Magister Pendidikan Kimia, Fakultas Matematika dan Ilmu Pengetahuan \\ Alam, Universitas Negeri Jakarta, Jl. Pemuda No. 10 Rawamangun, Jakarta, 13220, Indonesia \\ ${ }^{\star}$ E-mail: lumypillena@gmail.com
}

\begin{abstract}
ABSTRAK
Penelitian ini bertujuan untuk mengetahui pengaruh media mobile learning dan kemampuan metakognitif terhadap keterampilan proses sains siswa pada materi asam basa. Penelitian ini dilaksanakan di SMA Negeri 48 Jakarta dengan sampel penelitian sebanyak 40 siswa yang terdiri dari 20 siswa yang memiliki kemampuan metakognitif tinggi dan 20 siswa yang memiliki kemampuan metakognitif rendah yang dipilih dengan teknik multi stage random sampling. Metode penelitian yang digunakan adalah quasi eksperimen dengan desain treatment by level $2 \times 2$ dan data yang diperoleh dianalisis dengan anova dua jalur. Hasil pengujian diperoleh $f_{\text {hitung }}>f_{\text {tabel }}(58,93>4,10)$ menunjukkan bahwa terdapat interaksi antara penggunaan media mobile learning dan kemampuan metakognitif; $f_{\text {hitung }}>f_{\text {tabel }}(10,94>4,10)$ menunjukkan terdapat perbedaan keterampilan proses sains pada kelompok siswa yang menggunakan mobile learning dan pembelajaran tradisional; qhitung > $q_{\text {tabel }}(10,98>4,33)$ menunjukkan terdapat perbedaan keterampilan proses sains siswa yang menggunakan media mobile learning dengan siswa yang menggunakan pembelajaran tradisional pada kelompok siswa yang memiliki kemampuan metakognitif tinggi dan $q_{\text {hitung }}>q_{\text {tabel }}(4,37>4,33)$ menunjukkan terdapat perbedaan keterampilan proses sains siswa yang menggunakan media mobile learning dan siswa yang menggunakan pembelajaran tradisional pada kelompok siswa yang memiliki kemampuan metakognitif rendah.
\end{abstract}

Kata kunci: kemampuan metakognitif, keterampilan proses sains, media mobile learning

\begin{abstract}
This study aims to determine effect of mobile learning and metacognitive abilities on science process skills of students in acid-base. This research was conducted at SMA 48 Jakarta with sample of 40 students consisting of 20 students with high metacognitive abilities and 20 students with low metacognitive abilities were selected by the technique of multi stage random sampling. The research method used quasi experimental with treatment by level of $2 \times 2$ design and analyzed by two-way anova. The results obtained $f_{\text {count }}>f_{\text {table }}(58.93>4.10)$ shows an interaction between mobile learning and metacognitive abilities; $f_{\text {count }}>f_{\text {table }}(10.94>4.10)$ shows there are differences in science process skills in groups of students who use mobile learning and traditional; $q_{\text {count }}>q_{\text {table }}$ (10.98 > 4.33) shows differences science process skills of students using mobile learning with traditional in high metacognitive abilities's group, $q_{\text {count }}>q_{\text {table }}(4.37>4,33)$ shows differences science process skills of students using mobile learning and traditional in low metacognitive abilities's group.
\end{abstract}

Keywords: metacognitive abilities, science process skills, mobile learning

DOI: https://doi.org/10.15575/jtk.v4i2.5132 
Pengaruh Media Mobile Learning dan

Kemampuan Metakognitif terhadap

Keterampilan Proses Sains Siswa

\section{PENDAHULUAN}

Salah satu masalah pokok dalam pembelajaran dewasa ini adalah hasil belajar sains siswa Indonesia tergolong rendah. Survei internasional tentang hasil belajar siswa yang dilakukan oleh IEA melalui TIMSS (Trends in International Mathematics and Science Study) menunjukkan bahwa hasil belajar anak Indonesia berada signifikan dibawah ratarata Internasional. Indonesia pada tahun 2015 berada diperingkat 36 dari 49 negara (TIMSS, 2015). Studi TIMSS menunjukkan kemampuan rata-rata siswa Indonesia merespon soal format uraian lebih rendah (kurang dari 35\%) dibandingkan kemampuan rata-ratanya dalam merespon soal format pilihan sekitar $45 \%$. Analisis soalsoal TIMSS 2007 dan 2011 dikemukakan oleh Bayraktar (Rahmawati, 2016) menunjukkan bahwa persoalan yang diujikan pada TIMSS cenderung mengevalusi keterampilan berargumen, pemecahan masalah, melakukan analisis dan sintesis, merumuskan hipotesis, membuat prediksi, merancang eksperimen, generalisasi, dan evaluasi prosedur eksperimen.

Pembelajaran kimia tidak hanya sekedar pengetahuan yang bersifat ilmiah saja, melainkan terdapat dimensi-dimensi ilmiah penting yang menjadi bagian di dalamnya. Dimensi-dimensi tersebut diantaranya yaitu muatan sains, dan proses dalam aktivitas ilmiah dan sikap ilmiah dari aktivitas sains. Muatan sains ini meliputi berbagai fakta, konsep, hukum, dan teori-teori, dan hal tersebutlah yang menjadi objek kajian ilmiah manusia. Proses dalam melakukan aktivitasaktivitas yang terkait dengan sains biasa disebut dengan keterampilan proses sains atau science process skills. Aktivitas-aktivitas sains dikerjakan oleh setiap ilmuan dengan menggunakan keterampilan proses sains ini. Keterampilan ini pun dapat bermanfaat dalam kehidupan sehari-hari ketika kita menemukan persoalan-persoalan keseharian dan perlu mencari jawabannya.

Keterampilan proses sains dan e-learning merupakan keterampilan yang dibutuhkan di abad 21 (WEFUSA, 2015), pemanfaatan teknologi ICT dalam pembelajaran sangat dibutuhkan untuk membentuk pembelajaran yang berkualitas. Pemanfaatan ICT dalam pembelajaran yang selama ini banyak digunakan adalah Power Point untuk presentasi serta internet (blog, email, website) (Husain, 2014). Hasil penelitian penggunaan ICT dalm pembelajaran pada materi asam basa dapat meningkatkan kemampuan interkoneksi multiple level representasi (IMLR) (Farida \& Sopandi, 2011), dapat memberikan pendidik dan peserta didik pengalaman yang baru yang tidak diperoleh di pembelajaran tradisional (Hadjerrouit, 2010), dapat meningkatkan kepercayaan diri dan motivasi peserta didik (Koc, 2005), memungkinkan peserta didik belajar di mana saja dan kapan saja serta menumbuhkan kemandirian (Cook, 2007) dan memungkinkan peserta didik membangun pengetahuannya sendiri (Faizal \& Rahman, 2013).

Perkembangan teknologi dan informasi saat ini telah mengembangkan handphone menjadi smartphone. Salah satu pemanfaatan smartphone di dunia pendidikan adalah mobile learning. Smartphone dapat digunakan dalam konten pembelajaran yang dikemas dengan bentuk yang lebih menyenangkan sehingga dapat memotivasi dan hasil belajar siswa yang lebih baik. M-Learning merupakan pembelajaran dengan perangkat tertentu, yang dapat digunakan setiap saat dan di setiap tempat (Boyinbode \& Akinyede, 2008). Hal ini sejalan dengan (Robson \& Corporation, 
Pengaruh Media Mobile Learning dan Kemampuan Metakognitif terhadap Keterampilan Proses Sains Siswa

2003) yang menyatakan bahwa mobile learning juga meningkatkan kemungkinan pembelajaran informal yang tidak terikat lokasi tertentu. Hal itu, menjadikan banyak peniliti yang tertarik untuk meneliti lebih jauh terkait mobile learning.

Siswa pada sekolah menengah dianjurkan menggunakan kemampuan metakognitifnya karena berhubungan dengan cara berpikir tentang pemikirannya yang dapat mengoptimalkan kemampuan otak dalam kesadaran berfikir, mengetahui akibat yang ditimbulkan, dan kesadaran diri yang sudah seharusnya dimiliki siswa sekolah menengah (Brown \& Brown, 2015). Siswa yang memiliki kemampuan metakognisi akan sadar tentang proses berpikir dan mengevaluasi diri terhadap hasil proses berpikir serta pengalamannya. Hal tersebut akan memperkecil kesalahan siswa dalam menyelesaikan masalah dan membantu siswa dalam mengidentifikasi strategi belajar yang baik.

Salah satu upaya yang telah dilakukan pemerintah yaitu dengan diterapkan kurikulum 2013. Kurikulum ini menganut pendekatan saintifik yang harus dilakukan guru di dalam kelas. Pendekatan ini mengedepankan keterampilan proses yang harus dimiliki siswa. Dalam meningkatan keterampilan proses sains, siswa juga diharapkan memiliki kemampuan metakognitif yang dapat menunjang hasil belajarnya, namun pembelajarannya dikemas dalam hal yang menyenangkan, seperti menggunakan mobile learning.

Perumusan masalah dalam penelitian ini adalah 1) mengetahui perbedaan keterampilan proses sains pada materi asam basa antara siswa yang dalam pembelajaran menggunakan media mobile learning dengan siswa yang menggunakan pembelajaran tradisional 2) mengetahui interaksi antara penggunaa media mobile learning dan kemampuan metakognitif terhadap keterampilan proses sains siswa pada materi asam basa, 3) mengetahui perbedaan keterampilan proses sains pada materi asam basa antara siswa yang dalam pembelajaran menggunakan media mobile learning dengan siswa yang tidak menggunakan media mobile learning pada kelompok siswa yang memiliki kemampuan metakognitif tinggi, 4) mengetahui perbedaan keterampilan proses sains pada materi asam basa antara siswa yang dalam pembelajaran menggunakan media mobile learning dengan siswa yang tidak menggunakan media mobile learning pada kelompok siswa yang memiliki kemampuan metakognitif rendah.

\section{METODE PENELITIAN}

Populasi dalam penelitian ini adalah siswa kelas XI IPA SMA Negeri 48 Jakarta. Sampel dalam penelitian ini adalah 40 siswa yang terdiri dari 20 siswa yang memiliki kemampuan metakognitif tinggi (10 siswa dari kelas dengan media mobile learning dan 10 siswa dari kelas dengan pembelajaran tradisional) dan 20 siswa yang memiliki kemampuan metakognitif rendah (10 siswa dari kelas dengan media mobile learning dan 10 siswa dari kelas dengan pembelajaran tradisional) terpilih melalui teknik multi stage random sampling.

Pendekatan yang digunakan pada penelitian ini adalah pendekatan kuantitatif dengan metode quasi eksperimen desain treatment by level $2 \times 2$. Dalam penelitian ini, mobile learning merupakan variabel treatment, sedangkan kemampuan metakognitif terdiri dari 
Pengaruh Media Mobile Learning dan Kemampuan Metakognitif terhadap Keterampilan Proses Sains Siswa

kemampuan metakognitif tinggi dan kemampuan metakognitif rendah merupakan variabel moderat. Adapun variabel terikat dalam penelitian ini adalah keterampilan proses sains. Desain penelitian disajikan pada Tabel 1 berikut:

Tabel 1. Desain Penelitian

\begin{tabular}{|c|c|c|}
\hline \multirow{2}{*}{$\begin{array}{c}\text { Kemampuan } \\
\text { Metakognitif } \\
\text { (B) }\end{array}$} & \multicolumn{2}{|c|}{ Media Pembelajaran (A) } \\
\hline & $\begin{array}{c}\text { Mobile } \\
\text { Learning }\left(\mathrm{A}_{1}\right)\end{array}$ & $\begin{array}{c}\text { Konvensional } \\
\text { (A2) }\end{array}$ \\
\hline Tinggi $\left(B_{1}\right)$ & $\mathrm{A}_{1} \mathrm{~B}_{1}$ & $A_{2} B_{1}$ \\
\hline Rendah $\left(B_{2}\right)$ & $A_{1} B_{2}$ & $A_{2} B_{2}$ \\
\hline
\end{tabular}

Ket:

$\mathrm{A}_{1}=$ Menggunakan media pembelajaran mobile learning

$\mathrm{A}_{2}=$ Menggunakan media pembelajaran tradisional

$\mathrm{B}_{1}=$ Kemampuan metakognitif tinggi

$\mathrm{B}_{2}=$ Kemampuan metakognitif rendah

\begin{tabular}{lll} 
Pengukuran & \multicolumn{2}{c}{ kemampuan metakognitif } \\
menggunakan & instrumen kemampuan \\
metakognitif yang mengacu pada & \\
Metacognitive Awarness Inventory (MAl)
\end{tabular} disusun oleh Schraw \& Dennison (Schraw, Gregory; Dennisom, 1994) yang disesuaikan dengan pembelajaran kimia yang berupa 30 pernyataan skala sikap yang dikembangkan dengan skala Likert 1 - 5 dan telah dilakukan validasi oleh dosen ahli dan siswa serta dilakukan uji reliabilitas dengan rumus Alpha Cronbach yang diperoleh nilai $r=0,91$. Instrumen ini diberikan kepada siswa pada awal sebelum pelaksanaan pembelajaran untuk mengelompokkan siswa dalam dua kelompok yaitu kelompok siswa dengan kemampuan metakognitif tinggi dan kelompok siswa dengan kemampuan metakognitif rendah.

Pengukuran keterampilan proses sains materi asam basa menggunakan instrumen keterampilan proses sains yang mengacu pada aspek-aspek keterampilan proses sains yang dikemukakan oleh Rustaman yang meliputi delapan aspek yaitu mengamati, berhipotesis, mengajukan pertanyaan, merancang percobaan, mengelompokkan, meninterpretasikan data, menerapkan konsep, dan berkomunikasi (Rahayu, 2011). Pengukuran keterampilan proses sains ini berupa delapan soal uraian yang telah dilakukan validasi oleh dosen ahli dan siswa serta dilakukan uji reliabilitas dengan rumus Alpha Cronbach yang diperoleh $r=0,918$. Data hasil uji keterampilan proses sains yang diperoleh dilakukan uji prasyarat analisis yaitu uji normalitas dengan uji Lilierfors $\left(L_{0}=0,1323\right.$ pada kelompok siswa $A_{1}, L_{0}=0,135$ pada kelompok siswa $A_{2}$ dengan $L_{\text {tabel }}=0,19$ dan $L_{0}$ $=0,1286$ pada kelompok siswa $A_{1} B_{1}, L_{0}=$ 0,1315 pada kelompok siswa $A_{1} B_{2}, L_{0}=0,1539$ pada kelompok $A_{2} B_{1}, L_{0}=0,176$ pada kelompok $A_{2} B_{2}$ dengan $L_{\text {tabel }}=0,19$ ) dan uji homogenitas dengan uji fisher $\left(f_{\text {hitung }}=1,67\right.$ dengan $f_{\text {tabel }}=2,21$ ) yang dilanjutkan dengan uji Bartlett $\left(x^{2}\right.$ hitung $=1,74$ dengan $x^{2}$ tabel $=$ $7,815)$. Selanjutnya dilakukan uji hipotesis pertama (main effect) dan hipotesis kedua (interaction effect) menggunakan teknik analisis varian (Anava) dua jalur sedangkan hipotesis ketiga (simple effect) dan hipotesis keempat (simple effect) menggunakan uji Tukey.

\section{HASIL DAN PEMBAHASAN}

Hasil pengujian hipotesis dengan Anava dua jalur pada Tabel 2 berikut. 
Pengaruh Media Mobile Learning dan Kemampuan Metakognitif terhadap Keterampilan Proses Sains Siswa

Tabel 2. Hasil Perhitungan Anava Dua Jalur

\begin{tabular}{|l|c|c|c|c|c|c|}
\hline \multicolumn{1}{|c|}{ Sumber Varians } & Db & JK & RJK & $\mathbf{F}_{\mathbf{h}}$ & $\mathbf{F}_{\mathbf{t}}(\boldsymbol{\alpha}=\mathbf{0 . 0 5})$ & Kesimpulan \\
\hline Antar Kolom (Ak) & 1 & 313.6 & 313.6 & 10.94 & 4.1 & $\mathrm{H}_{0}$ Ditolak \\
\hline Antar Baris (Ab) & 1 & 144.4 & 144.4 & 5.04 & 4.1 & $\mathrm{H}_{0}$ Ditolak \\
\hline Interaksi (I) & 1 & 1690 & 1690 & 58.93 & 4.1 & $\mathrm{H}_{0}$ Ditolak \\
\hline Antar kelompok (A) & 3 & 2148 & 716 & & & \\
\hline Dalam kelompok (D) & 36 & 1032.4 & 28.68 & - & - & \\
\hline Total di Reduksi (TR) & 39 & 3180.4 & - & - & - & \\
\hline Rerata/ koreksi (R) & 1 & 242113.6 & - & - & - & \\
\hline Total (T) & 40 & 245294 & - & - & - & \\
\hline
\end{tabular}

Sedangkan pengujian dengan uji Tukey diberikan pada Tabel 3 berikut.

Tabel 3. Hasil pengujian Tukey

\begin{tabular}{|c|c|c|c|c|}
\hline Kelompok & $\mathbf{N}$ & $\mathbf{Q}_{\text {hitung }}$ & $\mathbf{Q}_{\text {tabel }}$ & Kesimpulan \\
\cline { 1 - 2 } $\mathbf{A}_{\mathbf{1}} \mathbf{B}_{\mathbf{1}}$ & 10 & \multirow{2}{*}{10.98} & \multirow{2}{*}{4.33} & \multirow{2}{*}{$\mathrm{H}_{0}$ ditolak } \\
\cline { 1 - 2 } $\mathbf{A}_{\mathbf{2}} \mathbf{B}_{\mathbf{1}}$ & 10 & & & \\
\hline $\mathbf{A}_{\mathbf{1}} \mathbf{B}_{\mathbf{2}}$ & 10 & \multirow{2}{*}{4.37} & \multirow{2}{*}{4.33} & \multirow{2}{*}{$\mathrm{H}_{0}$ ditolak } \\
\cline { 1 - 2 } $\mathbf{A}_{\mathbf{2}} \mathbf{B}_{\mathbf{2}}$ & 10 & & & \\
\hline
\end{tabular}

\subsection{Perbedaan Keterampilan Proses Sains pada Materi Asam Basa antara Siswa yang dalam Pembelajaran Menggunakan Media Mobile Learning dengan Siswa yang Menggunakan Pembelajaran Tradisional}

Dari hasil pengujian hipotesis pada kelompok siswa yang menggunakan pembelajaran dengan media mobile learning dan kelompok siswa yang menggunakan pembelajaran tradisional maka diperoleh $F_{\text {hitung }}=10,59$ dengan nilai $F_{\text {tabel }}=4,20$. Oleh karena $F_{\text {hitung }}>$ $\mathrm{F}_{\text {tabel }}$ maka $\mathrm{H}_{0}$ ditolak. Dari hal tersebut maka dapat disimpulkan bahwa terjadi perbedaan hasil keterampilan proses sains siswa antara siswa yang menggunakan media mobile learning dengan siswa yang menggunakan pembelajaran tradisional.

Pada kelompok siswa yang menggunakan pembelajaran denga media mobile learning diperoleh rata-rata nilai keterampilan proses sains 90,02 dengan standar deviasi 9,7 sedangkan pada kelompok siswa kelas kontrol yang menggunakan pembelajaran tradisional diperoleh rata-rata nilai keterampilan proses sains 72,05 dengan standar deviasi 5,5. Hasil tersebut terlihat pada grafik berikut.

Mobile learning adalah sebuah pendekatan pembelajaran elektronik (e-learning) yang menggunakan perangkat mobile, namun juga bisa dipandang sebagai pengalaman belajar yang berbeda. Fitur yang paling penting di lingkungan mobile adalah mobilitas itu sendiri dimana informasi bisa diakses dimana saja dan kapan saja tidak dibatasi tempat dan waktu, siswa tidak perlu menunggu waktu tertentu untuk belajar atau pergi ke tempat tertentu untuk belajar.

Kelebihan dari mobile learning yaitu, (1) memudahkan siswa untuk belajar dimanapun dan kapanpun tanpa dibatasi ruang dan waktu, (2) hemat biaya, (3) fleksibilitas kecepatan belajar, (4) fitur yang terdapat dalam mobile learning mampu meningkatkan keterampilan proses sains siswa, (5) mobile learning merupakan metode baru untuk menumbuhkan motivasi dan kemandirian siswa untuk belajar. Hal tersebut didukung oleh (Hung dkk., 2014) menunjukkan bahwa media mobile learning dapat meningkatkan minat belajar siswa. Penggunaan media

This is an open access article under CC-BY-SA license (https://creativecommons.org/licenses/by-sa/4.0/) 
Pengaruh Media Mobile Learning dan Kemampuan Metakognitif terhadap Keterampilan Proses Sains Siswa

pembelajaran mobile learning memiliki efek positif pada kinerja siswa (Jabbour, 2013). Ini juga mempengaruhi interaksi antara siswa dan guru dalam proses pembelajaran dan memiliki dampak belajar menjadi lebih aktif. Berdasarkan penelitian, dianggap bahwa siswa yang diajarkan dengan menggunakan media pembelajaran mobile learning dapat belajar secara mandiri kapan saja dan di mana saja untuk menambah pengetahuan mereka. Dengan demikian, penggunaan media mobile learning mobile dapat berdampak pada hasil belajar siswa yang tinggi karena mereka mengembangkan pemahaman yang lebih dalam tentang materi pelajaran. Seperti yang diusulkan oleh (Males dkk., 2017), teknologi berkontribusi pada peningkatan hasil belajar siswa di pendidikan tinggi.

Keterampilan dan proses siswa mencari tahu tentang sesuatu sama dengan ilmuan ketika belajar. Siswa dapat belajar meniru kebiasaan ilmuan dalam menyelesaikan masalah dan melakukan percobaan. Hal ini dapat dilakukan dengan menggunakan media yang dapat memotivasi berupa stimulus media visual, sehingga dalam pembelajaran tidak hanya mengajarkan konteks materi saja tetapi mengajarkan keterampilan berpikir. Diharapkan dengan media mobile learning ini dapat meningkatkan keterampilan berpikir siswa.

Pada pembelajaran dengan menggunakan media mobile learning terjadi proses yang dapat memberi stimulus kepada siswa untuk berpikir jika dibandingkan dengan penggunaan media tradisional, karena dengan media mobile learning siswa bisa mengakses materi pembelajaran atau informasi dimana saja dan kapan saja dengan kecepatan belajar masing-masing dan akan tercipta proses pembelajaran kooperatif dan kalaboratif sehingga timbul proses berpikir kritis, pemecahan masalah dan berpikir kreatif yang secara otomatis akan meningkatkan keterampilan proses sains. Selain itu di dalam mobile learning terdapat video, gambar, dan animasi yang dapat menumbuhkan keterampilan proses sains dalam kegiatan pembelajaran.

Berbeda halnya dengan siswa yang diajarkan dengan menggunakan media tradisional, dalam hal ini menggunakan media powerpoint. Umumnya media powerpoint hanya berupa tayangan yang dikombinasikan dengan metode ceramah yang guru berikan ketika menjelaskan materi pembelajaran di Kelas. Media powerpoint ini lebih berpusat pada guru (teacher centered) sehingga pebelajaran menjadi monoton karena siswa menerima sumber informasi hanya dari guru secara teoritik akibatnya berpikir kritis siswa hanya sebatas menghafal dan mengingat yang tingkatan berpikirnya masih rendah, sehingga dapat menurunkan motivasi dan kemandirian belajar siswa serta dapat mempengaruhi proses berpikir dan proses keterampilan siswa.

Berdasarkan penjelasan ini, pembelajaran menggunakan media tradisional menjadi kurang efektif karena dikendalikan oleh guru yang menyampaikan materi pembelajaran daripada melibatkan siswa dalam kegiatan pembelajaran.

\subsection{Pengaruh Interaksi antara Penggunaan Media Mobile Learning dan Kemampuan Metakognitif terhadap Keterampilan Proses Sains Siswa pada Materi Asam Basa}

Hasil pengujian hipotesis diperoleh nilai $F_{\text {hitung }}$ (Fh) sebesar 65,24 dengan nilai $F_{\text {tabel }}$ pada taraf signifikansi 0,05 sebesar 4,20. Oleh karena nilai 
Pengaruh Media Mobile Learning dan Kemampuan Metakognitif terhadap Keterampilan Proses Sains Siswa

$F_{\text {hitung }}>\mathrm{F}_{\text {tabel }}$ maka $\mathrm{H}_{0}$ ditolak sehingga dapat disimpulkan bahwa terdapat pengaruh interaksi antara penggunaan media mobile learning dan kemampuan metakognitif terhadap keterampian proses sains siswa pada materi asam basa.

Adanya interaksi membuktikan bahwa penggunaan media mobile learning dan media tradisional masing-masing memberikan pengaruh yang berbeda terhadap keterampilan proses sains siswa jika diterapkan pada kelompok siswa yang memiliki kemampuan metakognitif yang berbeda.

Keterampilan proses sains adalah adalah perangkat kemampuan kompleks yang biasa digunakan oleh para ilmuwan dalam melakukan penyelidikan ilmiah ke dalam rangkaian proses pembelajaran yang meliputi: (1) mengamati (observasi), (2) meramalkan, (3) merencanakan percobaan, (4) menafsirkan pengamatan, (5) mengukur, (6) mengklasifikasikan, (7) Menerapkan konsep, (8) Mengomunikasikan, (9) Menyimpulkan, (10) Mengajukan pertanyaan, yang dapat ditingkatkan dengan cara memberikan stimulus berupa media mobile learning sehingga dapat memotivasi siswa untuk berpikir lebih kompleks.

Kemampuan metakognitif adalah kemampuan siswa untuk mengatur proses kognitif yang terjadi dalam dirinya berupa kemampuan tentang berpikirnya, cara yang digunakan dalam belajar, dan bagaimana cara menggunakan pengetahuannya dan pengetahuan tentang pengaturan kognitifnya yaitu kemampuan melakukan perencanaan, strategi untuk mengatur informasi yang diperoleh, memantau proses berpikirnya, strategi untuk memperbaiki pemahaman yang salah, dan mengevaluasi keefektifan strategi yang digunakan. Secara sederhana kemampuan metakognitif dapat diartikan sebagai kemampuan berpikir secara mendalam yang harus dimiliki siswa.

Sejatinya keterampilan proses sains membutuhkan lingkungan belajar yang ideal untuk mendukung pengetahuan siswa untuk menggunakan pengetahuan metakognitifnya, sehingga jika kemampuan metakognitif siswa baik maka akan lebih membantu pemahaman siswa. Selain itu, penggunaan mobile learning dalam pembelajaran dapat meningkatkan keterampilan proses sains.

Kemampuan metakognitif pada proses pembelajaran ditunjukkan dengan siswa tidak hanya mengandalkan powerpoint atau penjelasan dari guru sebagai sumber belajar melainkan siswa memiliki keingintahuan yang lebih dalam untuk mencari informasi dari sumber lain, mampu bertanggung jawab terhadap kegiatan pembelajarannya sendiri. Siswa yang memiliki kemampuan metakognitif lebih dengan media pembelajaran mobile learning diduga akan memiliki hasil belajar yang lebih baik dibandingkan dengan yang memiliki kemampuan metakognitif dengan menggunakan media tradisional.

Agar dapat mengoptimalkan pembelajaran, maka siswa perlu diupayakan menjadi mandiri. Kemandirian belajar siswa sangat penting sehingga mereka menjadi bertanggung jawab untuk proses pembelajaran. Implementasi pembelajaran mandiri ditunjukkan dalam proses pembelajaran di mana siswa tidak hanya mengandalkan buku atau penjelasan guru sebagai sumber belajar utama tetapi mereka juga terlibat dalam proses pembelajaran bersama. Berdasarkan uraian di atas, dapat disimpulkan ada interaksi antara 
Pengaruh Media Mobile Learning dan Kemampuan Metakognitif terhadap Keterampilan Proses Sains Siswa

media pembelajaran dan kemandirian belajar terhadap hasil belajar siswa.

\subsection{Perbedaan Keterampilan Proses Sains} Pada Materi Asam Basa antara Siswa yang dalam Pembelajaran Menggunakan Media Mobile Learning dengan Siswa yang Tidak Menggunakan Media Mobile Learning pada Kelompok Siswa yang Memiliki Kemampuan Metakognitif Tinggi

Berdasarkan hasil pengujian hipotesis, diperoleh nilai $Q_{\text {hitung sebesar 11,53 dengan }}$ nilai $Q_{\text {tabel }}$ pada taraf signifikansi 0,05 sebesar 4,20. Oleh karena nilai $Q_{\text {hitung }}>Q_{\text {tabel, }}$ maka $H_{0}$ ditolak sehingga dapat disimpulkan bahwa terdapat perbedaan keterampilan proses sains materi asam basa antara siswa yang menggunakan media mobile learning dengan siswa yang menggunakan pembelajaran tradisional pada kelompok siswa yang memiliki kemampuan metakognitif tinggi.

Nilai rata-rata keterampilan proses sains pada kelompok siswa yang memiliki kemampuan metakognitif tinggi diberi perlakuan dengan menggunakan mobile learning dalam pembelajarannya diperoleh sebesar 89,45 dengan standar deviasi 6,75, sedangkan kelompok siswa yang memiliki kemampuan metakognitif tinggi diberi perlakuan dengan menggunakan media tradisional memiliki rata-rata nilai keteampilan proses sains 71,25 dengan standar deviasi 4,33.

Rata-rata nilai keterampilan proses sains yang menggunakan media mobile learning dengan kemampuan metakognitif tinggi memiliki hasil lebih tinggi dibandingkan kelompok siswa yang menggunakan pembelajaran tradisioanal dengan kemampuan metakognitif tinggi.

Siswa yang memiliki kemampuan metakognitif tinggi cenderung memiliki keingintahuan lebih dalam, mendiagnosis kebutuhan belajar, mampu memonitor dan mengontrol belajar, memandang kesulitan sebagai tantangan, mencari dan memanfaatkan sumber belajar yang relevan. Siswa yang memiliki karakteristik seperti ini tentunya akan lebih mudah menguasai pelajaran dibandingkan dengan siswa yang tidak memiliki karakteristik tersebut.

Jika kemampuan metakognitif dihubungkan dengan media pembelajaran yang digunakan dalam proses pembelajaran, media mobile learning yang cocok untuk siswa yang memiliki kemampuan metakognitif tinggi. Hal ini dikarenakan media mobile learning memberikan keunggulan untuk dapat digunakan kapan dan dimana saja oleh siswa sehingga siswa dapat memperoleh pengetahuan secara lebih mendalam dan bermakna. Kemampuan metakognitif cenderung mempengaruhi apa, kapan, dan bagaimana belajar, dan meningkatkan kemungkinan terlibat dalam aktivitas yang akan membantu siswa belajar dan menuntun siswa untuk memiliki kinerja yang lebih baik dan akibatnya akan menghasilkan keterampilan proses sains yang tinggi. Hal ini didukung oleh (Branch \& Branch, 2016) bahwa siswa yang memiliki kemampuan metakognitif tinggi lebih mandiri dan memiliki performa kelas yang bagus. 
Pengaruh Media Mobile Learning dan Kemampuan Metakognitif terhadap Keterampilan Proses Sains Siswa

Siswa yang diajarkan dengan menggunakan media tradisional, dalam hal ini menggunakan media powerpoint yang dikombinasikan dengan metode ceramah yang guru berikan ketika menjelaskan materi pembelajaran di Kelas, siswa akan cenderung bosan dengan penggunaan media yang kurang menarik. Media powerpoint ini lebih berpusat pada guru (teacher centered) sehingga pebelajaran menjadi monoton karena siswa menerima sumber informasi hanya dari guru secara teoritik akibatnya berpikir kritis siswa hanya sebatas menghafal dan mengingat yang tingkatan berpikirnya masih rendah, sehingga kurang efektif jika digunakan pada siswa yang memiliki kemampuan metakognitif tinggi.

Keterampilan metakognitif merupakan suatu kemampuan yang dapat memotivasi siswa untuk dapat mengontrol proses berpikirnya dalam belajar, dengan menggunakan media mobile learning sangat dibutuhkan kemampuan metakognitif yang tinggi sehingga keterampilan proses sains dapat tercapai.

\subsection{Perbedaan Keterampilan Proses Sains pada Materi Asam Basa antara Siswa yang dalam Pembelajaran Menggunakan Media Mobile Learning dengan Siswa yang Tidak Menggunakan Media Mobile Learning pada Kelompok Siswa yang Memiliki Kemampuan Metakognitif Rendah}

Berdasarkan hasil pengujian hipotesis, diperoleh nilai $Q_{\text {hitung }}$ sebesar 4,83 dengan nilai $Q_{\text {tabel }}$ pada taraf signifikansi 0,05 sebesar 4,20. Oleh karena $Q_{\text {hitung }}>\mathrm{Q}_{\text {tabel }}$ maka $\mathrm{H}_{0}$ ditolak sehingga dapat disimpulkan bahwa terdapat perbedaan keterampilan proses sains materi asam basa antara siswa yang menggunakan media mobile learning dengan siswa yang menggunakan pembelajaran tradisional kelompok siswa yang memiliki kemampuan metakognitif rendah.

Pada kelompok siswa yang memiliki kemandirian belajar rendah yang diberikan perlakuan dengan web pembelajaran memperoleh rata-rata nilai literasi sains 72,00 dengan standar deviasi 4,00 sedangkan kelompok siswa yang memiliki kemandirian belajar rendah yang diberikan perlakuan dengan media tradisional memiliki rata-rata nilai literasi sains 79,88 dengan standar deviasi 4,69 .

Siswa yang mempunyai kemampuan metakognitif tinggi dapat dilihat dari kegiatan belajarnya, ia mampu mengontrol belajarnya sendiri, tidak perlu disuruh bila belajar dan kegiatan belajar dilaksanakan atas inisiatif dirinya sendiri. Siswa dengan kemampuan metakognitif tinggi memiliki kesadaran penuh dalam belajar sendiri dan dalam mengambil segala keputusan, belajar diusahakan sendiri dan bertanggung jawab sepenuhnya dalam proses belajar tersebut (Valencia-vallejo et al., 2019). Sedangkan siswa yang memiliki kemampuan metakognitif rendah cenderung kurang percaya diri dalam mengerjakan sesuatu sehingga memberikan hasil yang tidak maksimal, kurang disiplin dalam belajar hal ini berkaitan dengan siswa kurang memiliki kemauan untuk belajar. Selain itu, kurang memiliki insiatif atau keingintahuan ketika mempelajari suatu hal atau materi yang sedang dipelajari, serta kurangnya usaha untuk memecahkan masalah, kurang bertanggung jawab terhadap komitmen pada tugas dan tanggung jawabnya, dan kurang 
Pengaruh Media Mobile Learning dan

Kemampuan Metakognitif terhadap

Keterampilan Proses Sains Siswa

memilliki motivasi untuk mengerjakan pekerjaannya dengan lebih baik. Karakterkarakter tersebut tentunya akan menghambat siswa dalam memperoleh keberhasilan dalam pembelajarannya.

Siswa yang memiliki kemampuan metakognitif rendah cenderung mengikuti proses pembelajaran apa adanya sehingga diperlukan pembelajaran yang disusun secara sistematis. Struktur materi pembelajaran juga cenderung diikuti sesuai dengan yang disajikan sehingga diperlukan materi pelajaran yang tersusun dengan baik dan sistematis. Proses pembelajaran dengan media tradisonal lebih cocok untuk siswa yang memiliki kemandirian belajar rendah. Hal ini dikarenakan siswa yang memiliki kemampuan metakognitif rendah cenderung menerima pembelajaran apa adanya, bergantung pada orang lain sehingga memerlukan orang lain (guru) untuk menjelaskan materi secara rinci. Sehingga penggunaan mobile learning pada siswa yang memiliki kemampuan metakognitif rendah membuat siswa kurang berminat sehingga menurunkan motivasi belajar dan berakibat pada menurunnya keterampilan proses sains siswa.

Keterampilan metakognitif merupakan suatu kemampuan yang dapat memotivasi siswa untuk dapat mengontrol proses berpikirnya dalam belajar, dengan menggunakan media mobile learning sangat dibutuhkan kemampuan metakognitif. Jika siswa memiliki kemampuan metakognitif yang rendah akan mengurangi ketercapaian keterampilan proses sains.

\section{KESIMPULAN}

Terjadinya interaksi antara penggunaan media mobile learning dengan kemampuan metakognitif menunjukkan bahwa penggunaan media mobile learning memiliki pengaruh yang berbeda pada kelompok siswa yang memiliki kemampuan metakognitif yang berbeda.

Nilai keterampilan proses sains siswa pada kelompok siswa yang diberikan perlakuan dengan menggunakan mobile learning dalam pembelajaran lebih tinggi dari pada kelompok siswa yang diberikan perlakuan pembelajran tradisional. Penggunaan media mobile learning membuat proses pembelajaran menjadi lebih menarik dan menyenangkan sehingga meningkatkan keterampilan proses sains siswa.

Nilai keterampilan proses sains siswa yang menggunakan media mobile learning lebih tinggi daripada siswa yang menggunakan pembelajaran tradisional pada kelompok siswa yang memiliki kemampuan mtakognitif tinggi, hal ini menunjukkan bahwa pembelajaran dengan media mobile learning cocok digunakan untuk siswa yang memiliki kemampuan metakognitif tinggi.

Nilai keterampilan proses sains siswa yang menggunakan pembelajaran dengan media mobile learning lebih rendah daripada siswa yang menggunakan pembelajaran tradisional pada kelompok siswa yang memiliki kemampuan metakognitif rendah, hal ini menunjukkan bahwa pembelajaran tradisional lebih cocok digunakan pada siswa yang memiliki kemampuan metakognitif rendah. 
Pengaruh Media Mobile Learning dan Kemampuan Metakognitif terhadap Keterampilan Proses Sains Siswa

\section{DAFTAR PUSTAKA}

Boyinbode, O. K., \& Akinyede, R. O. (2008). Mobile Learning: An Application Of Mobile And Wireless Technologies In Nigerian Learning System. International Journal of Computer Science and Network Security, 8(11), 386-392.

Branch, M., \& Branch, M. (2016). The Effect of Metacognition on Educational Performance and Self-Directed Learning in Sixth Grade Female Students of Shiraz Zone Two. Mediterranean Journal of Social Sciences, 7(2), 49-53.

Cook, D. A. (2007). Web-based learning: pro, cons and controversies. Clinical Medicine, $7(1), 37-42$.

Faizal, M., \& Rahman, A. (2013). The Effectiveness of Web-based Multimedia Applications Simulation in Teaching and Learning. International Journal of Instruction. 6(2).

Farida, I., Liliasari \& Sopandi, W. (2013). Pembelajaran Berbasis Web untuk Meningkatkan Kemampuan Interkoneksi Multipel Level Representasi Mahasiswa Calon Guru pada Topik Kesetimbangan Larutan Asam-Basa. Chemica, 12(1).

Hadjerrouit, S. (2010). Developing Web-Based Learning Resources in School Education: A User-Centered Approach. Interdiciplinary Journal of E-Learning and Learning Object, 6.

Hung, C., Huang, I., \& Hwang, G. (2014). Effects of Digital Game-based Learning on Students' Self-Efficacy, Motivation, Anxiety and Achievements in Learning Mathematics. Journal of Computers in Education, 1, 151-166

Husain, C. (2014). Pemanfaatan Teknologi Informasi dan Komunikasi dalam Pembelajaran di SMA Muhammadiyah
Tarakan. Jurnal Kebijakan dan Pengembangan Pendidikan, 2(2), 184-192.

Jabbour, K. K. (2014). An Analysis of The Effect of Mobile Learning on Lebanese Higher Education. Informatics in Education, 7(2), $1-15$.

Jr, H. F. O. N., Brown, R. S., \& Brown, R. S. (2015). Differential Effects of Question Formats in Math Assessment on Metacognition and Effect Differential Effects of Question Formats in Math Assessment on Metacognition and Affect.

Koc, M. (2005). Individual Learner Differences In Web-based Learning Environments: From Cognitive, Affective and Social-cultural Perspectives. Turkish Online Journal of Distance Education, 6(4), 12-22.

Males, S., Bate, F., \& Macnish, J. (2017). The impact of mobile learning on student performance as gauged by standardised test (NAPLAN) scores, Research context, 27(1), 99-114.

Rahayu, E. (2011). Dengan Pendekatan Keterampilan Proses untuk Meningkatkan Hasil Belajar dan Kemampuan Berpikir Kreatif Siswa. Jurnal Pendidikan Fisika Indonesia, 7(2).

Rahmawati. (2016). Hasil TIMSS 2015. 1-10.

Robson, R., \& Corporation, E. (2003). Mobile Learning and Handheld Devices in the Classroom.

Schraw, Gregory, Dennisom, R. S. (1994). Assessing Metacognitive Awareness, Contemporary Educational Psychology, 19(4), 460-475.

Valencia-Vallejo, N., López-Vargas, O., \& Sanabria-Rodríguez, L. (2019). Effect of a metacognitive scaffolding on self-efficacy, metacognition, and achievement in elearning environments. Knowledge Management \& E-Learning: An International Journal, 11(1), 1-19

Jurnal Tadris Kimiya 4, 2 (Desember 2019): 157-167

This is an open access article under CC-BY-SA license (https://creativecommons.org/licenses/by-sa/4.0/) 